\title{
Research on Accounting Integrity and Professional Ethics Education in China's Social Transformation
}

\author{
Jingyi Zhao \\ School of Accounting, Jilin Business and Technology College,No. 1666 Kalun Lake Street, \\ Changchun, Jilin province china(PRC)
}

172740537@qq.com

Keywords: Social transition; Integrity; Professional ethic; Accounting integrity; The accounting professional ethics

\begin{abstract}
This article attempted to research the problem of integrity and professional ethic education of accounting under the background of social transition in china. With the questionnaire and statistical method, analysis of the Integrity characteristics of this period. And combining the reality of accounting integrity and professional ethics, puts forwards some suggestions of the problem about accounting integrity and professional, and then proposes more feasible measures that more can meet the demand of social development.

At present, Politic, economy, culture and other fields are facing critical period of transformation in china. And then, what are the special appearance of social transformation? And Performance will bring some opportunities or challenges to the development of accounting integrity and professional ethics education. The author discusses the problem is facing the challenges we need to put forward some suggest such as more feasibility, and more steadily the rationalization proposal about the development of accounting integrity and professional ethics education. Finally, achieving to solve the problem about accounting development scientifically.
\end{abstract}

\section{Implications for Defining and Background Analyze}

Social Transformation. Refers to the social transformation of politics, economy and culture comprehensive reform of social history. During this period, the socialist political system more secure; economy booming, economic contents are increasingly complicated; The comprehensive development of social culture and all kinds of professional culture gradually rise. To sum up, social entered a critical period of the comprehensive quantitative change.

Accounting Integrity and Professional Ethics. Integrity and professional ethics refers to the accounting personnel in the working process of the integrity and ethical standards. Specific performance for, On the one hand, Accountant can provide reliable information to the relevant demanders; On the other hand ,Accounting in combination with their own moral qualities and technical expertise In the service of enterprise and society in order to decision-making process that provide more real, more reliable accounting information and professional value.

Accounting Integrity and Professional Ethics Education. The essence of education is to cultivate, and in line with accounting education is to cultivate accounting personnel engaged in professional work. The current situation, accounting honesty and professional moral education is the good faith education institutions in the process of professional education and how to carry out comprehensive and professional ethics education, and promote the cultivation of accounting talents in the industry will internal integrity quality service into a professional credibility of specific process, then to comprehensively promote the ultimate goal of accounting integrity and professional ethics culture construction. 


\section{The Particularity of Accounting Integrity and the Particularity of Professional Ethics in the Period of Chinese Social Transformation}

During this period, As the main aspects of accounting, professional ethics anomie of accounting honesty and professional moral anomie, and a decrease industry credibility problem highlights more obvious, mainly due to the accounting is directly related to economic development. During this period, it Can be divided into accounting behavior anomie and accounting integrity and professional ethics anomie. Specific accounting behavior anomie can be shown as: withholding income, income of inflated, and illegal tax evasion, virtual estimated cost, adjust the profit violation and report a false aspects such as illegal, illegal operation; And it is this kind of professional behavior anomie problems eventually led to the distortion of accounting information, accounting profession descent and accounting personnel professional credibility, integrity level of economic information imbalance, hindered economic development. And if you're going to solve the problem at the root of the problem, you're going to have to help the accounting practitioners to set the right career values, and education is the most effective way.

\section{The Current Situation of Accounting Integrity and Professional Moral Education in Chinese Social Transformation}

Current Situation of Curriculum Design of Accounting Professional Ethics Education. Has always been our country's education is given priority to with exam-oriented education, even out of high school into the university, the students are busy everyday level, textual research for work such as "all ready". Almost including the main body of education institutions, students, and so on all the parties have ignored the good faith education, while the neglected education should include two aspects of basic education, professional education integrity. The basic integrity of education includes education and education. Professional integrity education can also contain professional skills education, professional integrity education etc. As main tool of economic management accounting is based on the professional skills in the process of professional education of theoretical knowledge of professional knowledge, professor contains basic accounting, financial accounting, cost accounting, management accounting, financial management, auditing, professional knowledge education and so on. In the accounting profession education system, honesty and professional ethics education are not serious.

To the basic accounting, for example, the author is not entirely statistics, in almost all the teaching materials involved in accounting integrity education is often only one chapter, and at the end of the textbook, in the specific teaching process, in the semester to complete all the chapters to explain and Professor only 10\%. In other courses, there are few special chapters on integrity education.

Table 1 The analysis of relevant content in the professional material

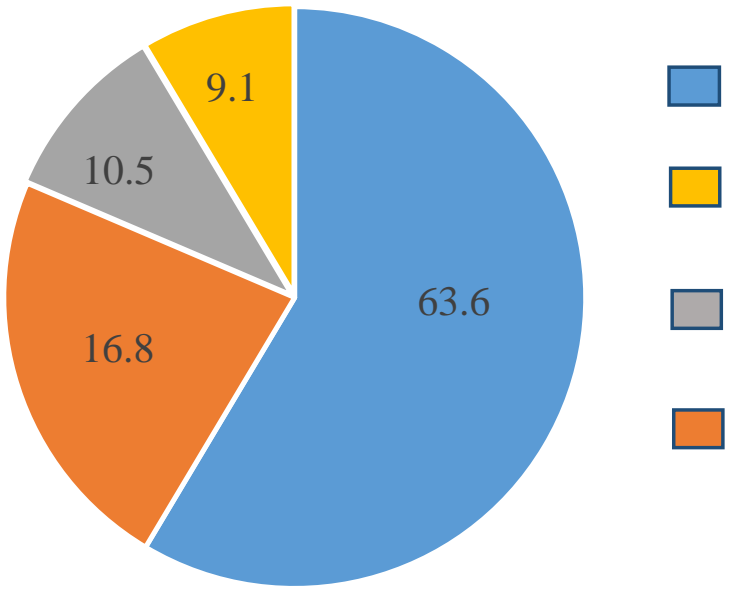

Accounting professional skills

Accounting professional ethics

Accounting standards

Knowledge of accounting basic theory 
The Current Situation of Honesty and Professional Ethics Education in Accounting Standards Education. Accounting standards can be said that accounting professional skills operating norms, should be regarded as accounting professional ethics and professional knowledge and technology of a strong combination. From a certain level can be said that accounting standards to ensure the integrity of accounting, accounting integrity is the basis of accounting professional ethics, and accounting professional ethics is the philosophical basis of accounting integrity. During professional learning, professional students through a variety of specialized courses in-depth study, and gradually in-depth study of the accounting standards on the monetary funds, on inventory, on long-term equity investment, fixed assets and other business operations specific regulatory provisions, these Provisions can guarantee the level of accounting integrity and the degree of truth.

Accounting standards can be said to be the standard of accounting professional skills, which should be a powerful combination of accounting professional ethics and professional knowledge technology. At present, our country of accounting standards issued in 2006, which including a basic standard and 38 specific standards, it is the accounting profession concrete operation standard, is accounting integrity and professional ethics and professional and technical knowledge of science, for the accounting information authenticity, objectivity, played a role, accounting honesty main goal is the accounting profession can conform to the laws and regulations, and accords with the specific requirements of accounting standards, in line with the requirements of the accounting professional ethics, for the country, for the society, to provide information demanders can reflect the economic reality of accounting information.

The Present Situation of Accounting Integrity and Professional Ethics Education. In the process of accounting professional, employees will face comes from the social, business owners, managers, and so on, a lot of pressure in the face of the accounting practitioners is to choose to follow a lot of pressure to the specific requirements of the accounting integrity and professional ethics, check the accounting personnel's professional ethics, or subject to pressure from the outside to a certain extent, depends on the selection of practitioners themselves, on the other hand should also be practitioners themselves with the influence of accounting honesty and professional moral level. I conducted a special survey of 200 accounting personnel, the final percentages are as follows:

Table 2 The present situation of Chinese accounting integrity and professional ethics education

\begin{tabular}{|l|l|l|l|l|l|}
\hline \multicolumn{1}{|c|}{ Target } & $\begin{array}{l}\text { General } \\
\text { Accountant }\end{array}$ & CPA & Tax Man & $\begin{array}{l}\text { Accounting } \\
\text { Instructors }\end{array}$ & Total \\
\hline $\begin{array}{l}\text { Keep accounting } \\
\text { professional ethics }\end{array}$ & $21.2 \%$ & $36.7 \%$ & $40 \%$ & $40.9 \%$ & $32.4 \%$ \\
\hline Subject to leadership & $19.3 \%$ & $10 \%$ & $23.3 \%$ & $16.7 \%$ & $17.4 \%$ \\
\hline Flexible processing & $32.6 \%$ & $30 \%$ & $16.7 \%$ & $18.1 \%$ & $25.1 \%$ \\
\hline Try to avoid & $17.5 \%$ & $16.7 \%$ & $20 \%$ & $20.2 \%$ & $18.8 \%$ \\
\hline Other & $9.4 \%$ & $6.6 \%$ & $0 \%$ & $4.5 \%$ & $6.3 \%$ \\
\hline
\end{tabular}

This shows, In the accounting process, practitioners will face from the community, business owners, business managers and so on the heavy pressure to face this heavy pressure accounting practitioners are chosen to follow the accounting integrity and professional ethics of the specific requirements, check accounting Personnel professional conduct, or choose to obey the pressure from the outside to a certain extent depends on the practitioners of their own choice, on the other hand should also be practitioners themselves have the integrity of accounting and professional 
ethics.

\section{The Reasons for the Lack of Accounting Integrity and Professional Ethics in Chinese Social Transformation Period}

At present, the economic development has called on the accounting professional talents demand: high quality, high integrity, high moral, high efficiency, high professional talents. From the results of the current accounting personnel is honesty and professional moral anomie is increasingly serious, visible, professional accounting Integrity education system and professional ethics education in China has not been enough attention, the integrity of professional practitioners and professional moral belief can't meet the demand of social political economic development comprehensive, this is the main reason for the lack of professional education can be: the lack of accounting credibility with the necessary understanding of the importance of professional ethics education; The knowledge system of accounting integrity and professional ethics education is incomplete; From accounting major to practice integrity and professional ethics level supervision is not enough.

Students in the professional knowledge learning process completely did not realize the professional integrity and professional ethics for the future importance of the practitioners, did not develop a good habit of good faith, did not form a good sense of professional ethics service. The fundamental reason, the students in school during the neglect of not only professional integrity education, but comprehensive integrity education. Throughout the university campus, late leave early, no reason absenteeism, examination plagiarism, examinations and so on the phenomenon of endless, the students themselves in the course of these dishonest acts did not even struggle, no fear, and become a natural choice, in this process There is no integrity constraints, there is no integrity of the file record of their dishonesty, and ultimately lead to this dishonesty will not play a practical effect on their future role in the practitioners.

\section{Accounting Integrity and the Reform of Professional Ethics Education in the Period of Social Transformation}

Strengthen Education to Meet the Need of Good Faith. The accounting Integrity and professional moral education process mainly is to help students form a good professional habit, finally with the sincere professional habit in the working process of the Chinese and foreign into professional moral quality as the goal of education behavior. The severity of the credit crisis in the face of the current accounting industry and the lack of education, must strengthen education, establish a basis of professional accounting course, based on the thinking of the accounting ethics, accounting integrity and professional ethics education for moral foundation of comprehensive accounting professional teaching system. In this way can help students to develop good habits of good faith, improve the students' comprehensive ability and integrity level can meet the social development demand for accounting industry and practitioners of integrity.

Strengthen Professional Attention and Make Full use of Professional Teachers' Professional Guidance. In the process of accounting integrity and professional ethics education, the influence of professional teachers is essential. From the current existing accounting professional teachers, even some professional teachers ignore the integrity and professional ethics education fundamentally, widespread emphasis on theoretical knowledge, light the phenomenon of integrity and moral and ethical education. We should strengthen the practice ability of professional teachers and play a guiding role in accounting practice. In other words, in the professional teachers should not only pay attention to the skills of theoretical knowledge, understand more about accounting practice should also work there may be no sincerity, don't abide by the professional ethics of the possibility that, in the relevant laws and regulations, professional ethics, so pay attention to strengthen in the process, positive effects play the exemplary role of educators and at the same time, help students form a good habit of honesty, sets up the good professional moral values, so as to make relevant knowledge of accounting integrity and professional ethics more guidance, to better play its effectiveness, and 
help students to fully understand the social transition of honesty really needs.

Establish a Complete Professional Ethics Investigation and Supervision System. To perfect professional irregularities investigation procedures specified in the relevant laws and regulations, working behavior of accounting personnel for more effective supervision, make illegal punishment actual warning role into full play. In this on the one hand, the author thinks that can draw lessons from the AICPA professional ethics to the specific requirements of the investigation procedure, establishing specific contains investigation to notify the defendant to collect evidence, the accused interview, review evidence to submit a hearing, the hearing decision to confirm the illegal facts, cancel, suspend, membership, warning, order the occupational education, forced to participate in the specified additional punishment, a comprehensive investigation procedure by accounting regulators such as the departments, to complete the accounting association, strengthen the legitimacy of the process, to avoid being at the same time make the results more scientific, more practical utility.

Play the Effectiveness of Education Accounting Integrity and Professional Ethics Education. How to let the accounting staff to participate in the continuing education to play its proper role, is a question worth thinking about. I believe that from two levels to solve this problem, on the one hand the premise is to ensure that the continuing education is true and effective to ensure that each accountant must be on time to participate in continuing education related courses in the absence of relevant assessment before freezing Its professional qualifications, to allow accounting staff peace of mind, practical education to continue the work of education. On the other hand, we must speed up the construction of accounting integrity and professional ethics education case.

Above all, the author believes that if we want to better solve the problem of accounting integrity and professional ethics education, we must combine the background of the domestic socio-economic environment to enhance the educational institutions and educators on the integrity of accounting and professional ethics education awareness, emphasizing the accounting staff The task of improving the overall quality of the imminent, aimed at the establishment of the recognition of the premise of the special accounting integrity and professional ethics education system. Combined with the reality of a comprehensive analysis of the reasons for failure and its solution strategy to strengthen the process of professional ethics in the case of case teaching and other means of training a variety of ways to stimulate students to learn enthusiasm, boring professional ethics is easier to understand and accept, and then in the accounting process consciously apply and comply with professional ethics and integrity of the relevant requirements.

\section{References}

[1] H. Li: Accounting Ethics, The Science Education Article Collects (In Chinese) (Shanghai University of Finance and Economics, China 2012), p.22.

[2] W.B. Li: Value Theory of Accounting (Ph.D., Northeastern University of Finance and Economics, China 2012), p.6.

[3] J.B. Lei: The Research on the Morality of Social Transformation in China is Studied, (Ph.D., Nanchang University, China 2013), p.26.

[4] L.D. Xu: Journal of the Taiyuan Urban Vocational and Technical College (In Chinese), (2015) No.6, p.132.

[5] S.L. Liao: The Study of Moral Life of Students in China During the Social Transition Period, Based on the Perspective of Public Philosophy(In Chinese), (MS., Guangxi Normal University, China 2015), p.18.

[6] J.L. Shi, L.W. Tang: Management Observation (In Chinese), (2016) No.19, p.136.

[7] J.W. Liu: Finance and Economics (Academic Edition) (In Chinese), (2016) No.5, p.185.

[8] F.F. Jian: Modernization of Business (In Chinese), (2015) No.1, p.169.

[9] J. Sun: Industry and Technology BBS (In Chinese), (2016) No.10, p.215.

[10]Q. Xue: Market Modernization (In Chinese), (2016) No.4, p.194. 